\title{
Review on Nutrient Management, Cycles, Flows and Balances in Different Farming Systems
}

\author{
Dereje Geremew \\ Ale Gore Agricultural Office, South Western Oromia Ethiopia
}

\begin{abstract}
Summary
Soil fertility management is continuously modified and adapted as conditions change in time and integrated plant nutrient management is a holistic approach to optimizing plant nutrient supply for the objective of adequately nourish the crop as efficiently as possible, while minimizing potentially adverse impacts to the environment Existence of life depends on continuous cycling of nutrients from the nutrient pool (in the abiotic component of environment) to the living beings and then back to the nutrient pool. These complex series of invisible, delicately balanced, and interrelated biochemical reactions fuel life on earth. Nutrients cycles have been substantially altered by human activities mainly agriculture with large positive and negative consequences for a range of ecosystem services and for human well-being and The presence of animals into the agricultural production system can modify the rates and flows of nutrient dynamics between the compartments of the system and Integrated crop-livestock systems can positively change the biophysical and socio-economic dynamics of farming systems, reestablishing sustainable rural development and promoting higher overall farm profitability. Soil nutrient balances reflect the net change in soil fertility and indicate trends in time, but do not necessarily determine the current state of soil fertility and can differ considerably between different crops, farming systems and agro-ecological zones
\end{abstract}

Keywords: Nutrients, nutrient cycle, nutrient balance

DOI: $10.7176 / \mathrm{JBAH} / 11-18-03$

Publication date:September $30^{\text {th }} 2021$

\section{Introduction}

Soil fertility management is continuously modified and adapted as conditions change in time and intensification of soil fertility depletion increases, when population pressure increases and suitable land becomes scarce (Boesen and Hansen, 2001). Eighty percent of arable land in Africa has low soil fertility and suffers from physical soil degradation as a result of massive nutrient loss caused by unsustainable soil management practices (Hengl T. et al., 2015).

In Ethiopia, low-input agricultural production systems and poor agronomic management practices, limited awareness of communities and absence of proper land-use policies have aggravated soil fertility degradation (Getachew and Tilahun, 2017). This has also encouraged the expansion of farming to marginal, non-cultivable lands, including steep landscapes and range lands (Getachew and Taye, 2005).

Existence of life depends on continuous cycling of nutrients from the nutrient pool (in the abiotic component of environment) to the living beings and then back to the nutrient pool. These complex series of invisible, delicately balanced, and interrelated biochemical reactions fuel life on earth. These nutrient cycles, driven directly or indirectly by incoming solar energy and gravity, include the carbon, oxygen, nitrogen, phosphorous, sulfur and hydrologic (water) cycles and biogeochemical (nutrient) cycles connect past, present and future forms of life (J.N. Galloway et al., 2004).

Nutrients cycles have been substantially altered by human activities mainly agriculture over the past two centuries (Vitousek et al. 1997, Bouwman et al. 2009), with large positive and negative consequences for a range of ecosystem services and for human well-being (MEA 2005a).

The integration of organic fertilizers, such as verm compost and conventional compost with inorganic fertilizers may improve and sustain crop yields without degrading soil fertility status. Integration of organic and inorganic fertilizers improved the crop yield compared to application of inorganic NP fertilizers alone (Getachew and Taye, 2005; Getachewet al., 2014). Integrated soil fertility management plays important role in restoring soil fertility and availability of plant nutrients, enhancing crop growth and productivity (Geteet al., 2010; Vanlauwe et al., 2010; Getachew and Tilahun, 2017).

Combined application of organic and inorganic fertilizers decreased soil bulk density, increased soil moisture, soil fertility, and improved maize grain quality (Ronget al., 2001). Technologies that combine mineral fertilizers with organic nutrient sources can be considered as better options in increasing fertilizer use efficiency, and providing a more balanced supply of nutrients (Donovan and Casey, 1998).

Integrated crop-livestock systems can positively change the biophysical and socio-economic dynamics of farming systems (Keulen and Schiere 2004), reestablishing sustainable rural development (Lemaire et al. 2003) and promoting higher overall farm profitability (Entzet al. 2005).

Soil tests are designed to help farmers predict the available nutrient status of their soils. Once the existing 
nutrient levels are established, producers can use the data to best manage what nutrients are applied, decide the application rate and make decisions concerning the profitability of their operations (Girma, 2016).

Sustainable crop production aims at maintaining high crop yield without adversely affecting ecosystems to meet the need of current as well as future generations. Since phosphorus in agriculture is the second most growth limiting macronutrient after nitrogen, its proper management in soil contributes significantly to sustainable crop production (Tilmanet al., 2002)To review nutrient management, cycles, flows and balances in different farming systems

\section{Nutrient management in different farming systems}

Many farming systems still rely on natural release of nutrients from the soil through mineralization and approximately $60-80 \%$ of the farm income was obtained at the expense of soil nutrient depletion, i.e. through un replenished nutrient uptake in marketable crops. Soil nutrient mining cannot be visualized easily and, therefore, indicators are often used to facilitate discussions on soil fertility management. Soil nutrient balances are a commonly used indicator (de Jageret al., 2001)

Producing food for the world population, but with limited impact on world ecosystems, will be a major global challenge with no single solution by managing nutrients cycles in agriculture (crop and livestock systems) can certainly contribute to the goal and Conserving and using nutrients efficiently may help to increase crop yields and limit environmental impact (Griffon ,2006).

Few full-scale studies of farm systems exist that permit the comparison of NUEs. However, conventional, integrated and organic farming systems for their effects on soils and plant nutrition, pests and diseases, animal husbandry, economics, biodiversity and environment, and food quality and health. The main conclusion with regard to nutrient management was the risk in organic systems of depleting soil nutrient reserves, especially of $\mathrm{K}$, owing to a lack of sources approved for use in organic systems (Tinker, 2000).

The fundamental doctrine of $\mathrm{N}$ management is to optimize efficiency of both introduced and native soil $\mathrm{N}$ by increasing the temporal and spatial coincidence between availability and root uptake of mineral N. Important management measures to improve $\mathrm{N}$ efficiency on farms include improved feeding efficiency of animals, reducing $\mathrm{NH}_{3}$ losses and improving $\mathrm{N}$ retention in the crop-soil system as well as timing, rate, source/material and method of supply. The latter implies crop sequences that incorporate cover (or catch) crops, judicious use of soil tillage, improved timing and use of animal manures, crop residues and mineral fertilizers and a suitable balance between the plant production potential and animal stocking density (Christensen, 2004 ; Crews and Peoples, 2005 )..

The main challenge for $\mathrm{N}$ management in farming systems is tightening the cycle, in particular those of livestock production systems (Oenemaet al. , 2007 ).

The total amount of $\mathrm{N}$ and $\mathrm{P}$ excreted in manure in 2011 was $\sim 120$ and $23 \mathrm{Tg}$ respectively. These quantities are similar to or larger than synthetic fertilizer $\mathrm{N}$ and $\mathrm{P}$ use worldwide. However, manure $\mathrm{N}$ and $\mathrm{P}$ are not effectively used in crop production due to: (1) the very uneven distribution of faeces and urine by grazing animals; (2) the often incomplete collection and inappropriate storage of faeces and urine from housed animals, with large volatilization and leaching losses; (3) the poor timing and method of manure application; (4) the slow release of organically bound nutrients in the manures; and (5) the relatively low prices of chemical fertilizers (Sutton et al. 2013; Strokalet al. 2016; Houet al. 2017).

Nitrogen is obtained by biological fixation by legumes, $\mathrm{P}$ from unrefined rock phosphate and $\mathrm{K}$ from seaweed and various K-containing minerals. Recycling of animal manures and composted wastes is central to organic management systems; deep-rooting plants are used to recycle nutrients from subsoil to topsoil (Gouldinget al. 2000)

$\mathrm{N}$ losses are strongly linked to the presence of livestock activities in the cycle. Eighty five percent $(85 \%)$ of total agricultural $\mathrm{N}$ losses, $72 \%$ of $\mathrm{NH}_{3}$ and $74 \%$ of $\mathrm{N}_{2} \mathrm{O}$ losses, are related to manure management. estimated global $\mathrm{NH}_{3}$ losses from agriculture to be: from housing and storage in mixed and pastoral systems $12-28 \%$, from grazing $6 \%$ to $17 \%$, from manure spreading in cropland and grassland $11-30$, and from $\mathrm{N}$ fertilizer use in cropland $10-18 \%$, and in grasslands $4-8 \%$.(Beusenet al., 2008)

At a cropping system level, management strategies available to improve overall P-use efficiency of cropping systems include the use of diverse crop rotations, the presence of cover or catch crops, and crop breeding for higher internal Puse efficiency, which will enhance crop P acquisition strategies. However, plant and microbial strategies need to be further improved, particularly the uptake of residual soil P (from applied fertilizers and manures) and subsoil $\mathrm{P}$ uptake (Richardson et al. 2011).

Phosphorus should be applied at the time of sowing of annual crops in bands in low-P soils. This reduces the fixation of the fertilizer $\mathrm{P}$ to a minimum as it allows the crop the best opportunity to compete with the soil $\mathrm{P}$ utilization (Mengelet al., 2001). If soil $\mathrm{P}$ content is higher or in the adequate range for crop growth, band and broadcast applications will be equally effective. The use of an adequate level of $\mathrm{P}$ for maximum economic yield is possible if $\mathrm{P}$ soil test calibration data are available for a given crop and soil type (Fageriaet al., 1997a). In 
order to achieve better soil $\mathrm{P}$ availability indices for any given soil type and crop species, detailed field calibrations are needed in relation to the $\mathrm{P}$ extracted by any particular extracting and the economic crop yield response to various soil $\mathrm{P}$ fertilization levels (Fageriaet al., 1997a).

Integration of organic amendments of $\mathrm{P}$ with inorganic source is significantly better than the use of mineral $\mathrm{P}$ fertilizers alone. Effectiveness of inorganic P fertilizers was increased and P recovery was improved with the addition of organic manure (Whalen and Chang, 2001). Furthermore, most crop plants utilize organic P sources efficiently by increasing production of phosphatases, increasing fungal and bacterial growth (Tarafdar and Claassen, 1988).

Repeated applications of chemical $\mathrm{P}$ fertilizers is expensive and can lead to the loss of soil fertility by disturbing microbial diversity and reducing crops yield (Gyaneshwaret al., 2002). The use of environmentfriendly alternative to applications of $\mathrm{P}$ fertilizers is gaining increasing attention (Bareaet al., 1997). In regions where inorganic P fertilizers application is expensive, use of phosphate rocks in combination of phosphatesolubilizing microorganisms (PSM) is seen as a viable al ternative.

Three major issues are correlated with the excessive fertilization of agricultural areas. The first issue that has to be addressed is the eutrophication affecting aquatic ecosystems. Another issue is the uneven terrestrial phosphate rock distribution, revealing a dipole of areas facing phosphorus over-accumulation and areas with restrictions in productivity due to major phosphorus deficiencies. Lately, an emerging issue is the assessment of the remaining global phosphorus reserves. The nutrient was characterized as a non-renewable resource, which should be efficiently exploited, taking into consideration the rules of sustainability (Cordell et al., 2009). The combination of organic inputs with fertilizers could play a substantial role in increasing the agronomic use efficiency of P fertilizer (Vanlauwe et al., 2010).

Globally, several efforts have been made targeting the improvement of phosphorus usage efficiency in crop fields and pastures (Schröder et al. 2011; Paganiet al. 2013). Among these is the 4R approach (Right product, Right rate, Right time, and Right place) by IFA (2009) and IPNI (2012),

Diversity and integration are often associated with sustainable and resource use efficient systems, in croplivestock mixed systems, intensification may occur through the introduction of animal traction, use of animal manure, fodder production, stall feeding and replacement of animals. Intensification creates opportunities for increasing integration due to increased production of crop residues that may be fed to livestock, and manure that may be used for cropping (Dalsgaard and Oficial, 1997).

Integrated crop-livestock systems are organized to maximize synergies and minimize trade-offs between crops and livestock sub-systems through the production of crops and livestock on the same area, concurrently or sequentially in rotation or succession (Moraeset al., 2014).

The result of an integrated system is that the whole is greater than the sum of its parts and resulting in having emergent properties (Anghinoniet al., 2013). These integrated crop-livestock systems are produce with minimal supply of inputs and technologies (Moraeset al., 2014). Crop-livestock integration is an effective means by which plant nutrients can be rapidly recycled within and between farms (Thornton and Herrero, 2001).

Integrated plant nutrient management is a holistic approach to optimizing plant nutrient supply. It includes: (1) assessing residual soil nutrient supplies, as well as acidity and salinity; (2) determining soil productivity potential for various crops through assessment of soil physical properties with specific attention to available water holding capacity and rooting depth; (3) calculating crop nutrient requirements for the specific site and yield objective; (4) quantifying nutrient value of on-farm resources such as manures and crop residues; (5) calculating supplemental nutrient needs (total nutrient requirement minus on-farm available nutrients) that must be met with "off - farm" nutrient sources; (6) developing a programme to optimize nutrient utilization through selection of appropriate nutrient sources, application timings and placement and the overall objective of IPNM is to adequately nourish the crop as efficiently as possible, while minimizing potentially adverse impacts to the environment (Roy et al., 2006).

\section{Nutrient cycle and flow in different farming systems}

The cycle of a nutrient in the soil-plant system can be defined as addition, transformation, and uptake by plants, loss from the soil-plant system, and immobilization (Fageria and Baligar, 2005a). The knowledge of nutrient cycling is important for the efficient use of soil nutrients, residues and fertilizers in the integrated crop-livestock system, because losses and additions of carbon and nutrients modify soil dynamics (Hentzet al., 2014).

Nutrient stocks flow and budgets are increasingly being used as tools for estimating nutrient build-up and decline so as to provide an understanding of the potential and suitability of land for agricultural production (Van den Bosch H, and Jager AD, Vlaming J (1998)).

The conservation of O.M is crucial for the chemical, biological and physical properties of the soil in temperate and tropical environments (Batista et al., 2014), and being an important constituent of nutrient reserve, whose availability can be rapid and intense, or slow and gradual, depending on the quantity, type of material and climatic conditions (Rosolem et al., 2007). 
Integrated crop-livestock systems can increase biodiversity via the attributes of organic matter provided by pastures resulting flora and fauna diversity, as well as microbial and faunal soil communities, change the soil and its physio-chemical properties (Lemaire et al. 2003). The heights of pasture management determines the total amount of dry matter produced by the aerial part and root system, the magnitude of the impact of the animal trampling and the amount of dry matter recycled in the system (Aguinagaet al., 2008).

Use of livestock for nutrient cycling and transfer to agricultural land presents another option of enhancing $\mathrm{N}$ recycling in the semi-arid conditions. It has been shown that livestock can recycle up to $48 \%$ of $\mathrm{N}$ intake as manure, which amounts to yearly average use on the cropped land of $1.2 \mathrm{~kg} \mathrm{ha}^{-1} \mathrm{~N}$ (Stoorvogel JJ, and Smaling EMA ,1990)).

The pastoral environment is particularly important to the colonization/extinction metapopulation processes of many organisms (eg. insects, mollusks) and is a forage resource for many birds and mammals, frequently being their reproduction site and pastures can be essential for biodiversity maintenance at the landscape level, being the habitat of invertebrates that are important to carbon and nitrogen cycles (Lemaire et al. 2003).

\section{Role of organic matter in nutrient cycling}

Organic matter (that is, C-based compounds of biological origin) plays several pivotal roles in determining nutrient availability toplants and largest labile stock of nutrients in soils, sediments, andwaters is typically contained in organic compounds. Since uptakeby plants is almost exclusively in the inorganic form, the biologically mediated process of organic matter decomposition is crucial to nutrient availability (Parton et al., 1988).

Organic matter provides energy for all microbial and faunal activities and thus allows them to build the micro aggregate structures that control soil hydraulic properties and serve to further conserve organic matter and deposition of straw on the soil surface of degraded soils attracts termites that feed on this resource and significantly improve water infiltration and storage in the galleries and porous constructions (Mandoet al., 1997).

The amorphous polymers act as reserves of nutrients, which are sequestered in their chemical structures for periods of centuries to millennia. Since its surface bears a significant electrical charge, organic matter (along with clay) is the main location on which the cationic and anionic forms of plant nutrients are retained prior to uptake, without being leached out ofthe soil (Lavelleand Spain 2001). O.M releases nutrients in a plant-available form upon decomposition. In order to maintain this nutrient cycling system, the rate of organic matter addition from crop residues, manure and any other sources must equal the rate of decomposition, and take into account the rate of uptake by plants and losses by leaching and erosion (FAO, 2005)

By breaking down carbon structures and rebuilding new ones or storing the $\mathrm{C}$ into their own biomass, soil biota plays the most important role in nutrient cycling processes and, thus, in the ability of a soil to provide the crop with sufficient nutrients to harvest a healthy product. The organic matter content, especially the more stable humus, increases the capacity to store water and store (sequester) C from the atmosphere (FAO, 2005).

Cycling of nutrients relies on the quality of agricultural soils, either directly through their capacity to receive nutrients and to convert them into or keep them in forms that are available to crops, or indirectly by governing the productivity and harvest ability of crops and thereby the effective capture of nutrients from soils (Keesstraet al., 2016).

The capacity of soil to cycle nutrients is a series of consecutive steps. These steps are (i) the capacity of a soil to receive and retain nutrients, the 'accommodation value'(AV), (ii) the capacity of a soil to make and to keep nutrients available for crop uptake, that is to ascertain the FV of the applied residue, (iii) the capacity of a soil to facilitate the recovery of plant-available nutrients, the RV and finally, (iv) the capacity of a soil to support the successful collection and export of produce containing apportion, defined by the Nutrient HI, of the nutrients acquired by the crop to a subsequent processor or consumer (Keesstraet al., 2016).

Organic inputs (crop residues and animal manures) are also an important source of nutrients, but their N, P, $\mathrm{Mg}$ and $\mathrm{Ca}$ content is only released following decomposition. By contrast, $\mathrm{K}$ is released rapidly from animal manures and crop residues because it is contained in the cell sap. Further, the amount of nutrients contained in organic resources is usually insufficient to sustain required levels of crop productivity and realize the full economic potential of a farmer's land and labor resources. Organic resources have multiple functions in soil, ranging from their influence on nutrient availability to modification of the soil environment in which plants grow and provide an energy source for soil microorganisms which drive the various soil biological processes that enhance nutrient transformation and other quality parameters of soil. (Fairhurst, T., 2012)

The response to fertilizer is greater when fertilizer is applied with added organic resources (e.g. animal manure) (line A, figure-1) and the response is even greater at higher rates of fertilizer input (line Bfigure-1,).The impact of animal manure on response to fertilizer depends on the amount of manure added. A much larger amount of fertilizer is required to reach yield at line C,figure-1 when no organic matter is used (line A) compared with the use of mineral fertilizer in combination with organic matter (line B). (Fairhurst, T., 2012) 


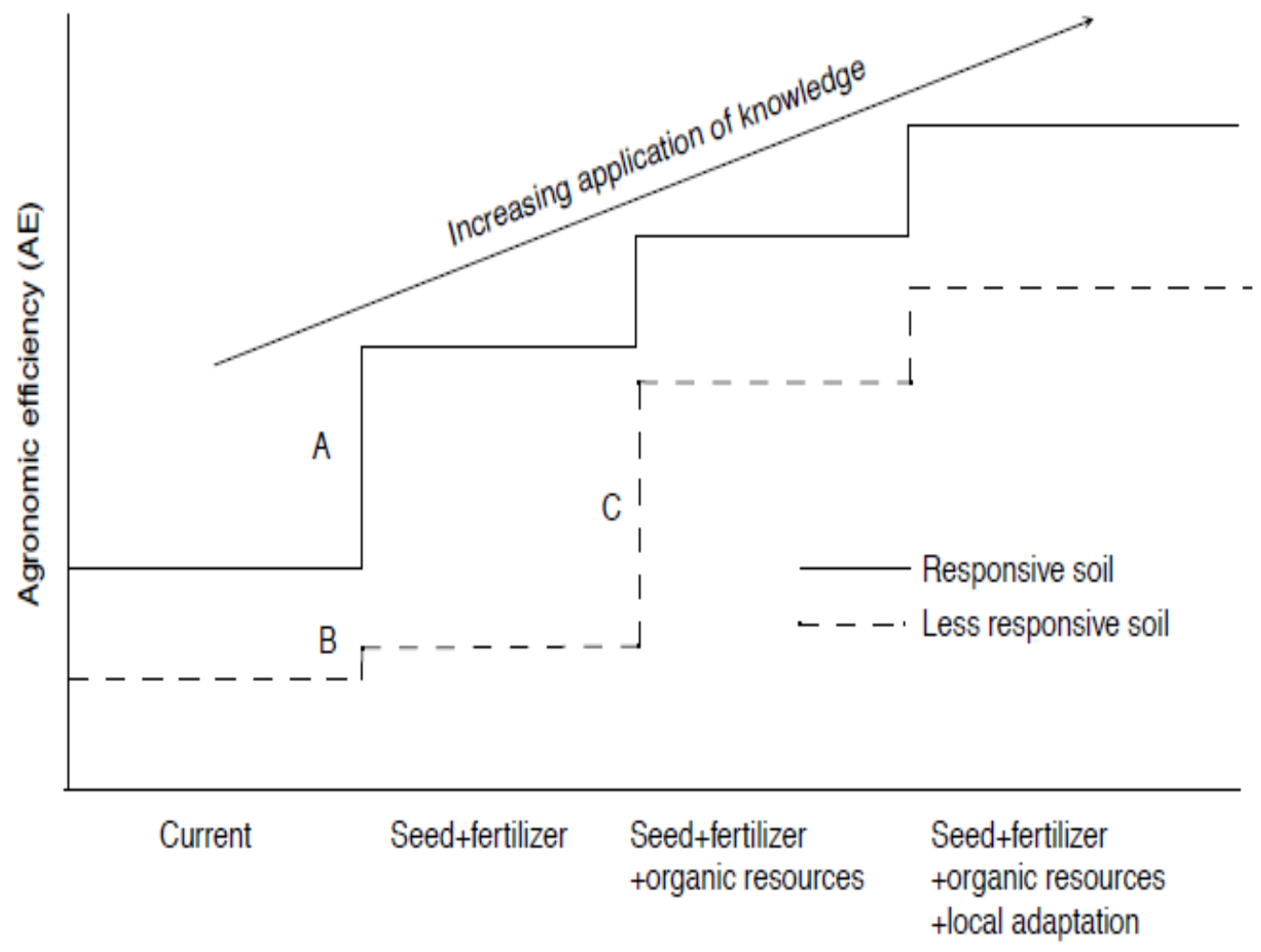

Move towards complete ISFM

Figure-1: Relationship between the agronomic efficiency (AE) of fertilizers and organic resource and the implementation of various components of ISFM.

Source: (Fairhurst, T., 2012)

Nitrogen $(\mathbf{N})$ is one of the most yield-limiting nutrients for crop production in the world. It is also the nutrient element applied in the largest quantity for most annual crops (Huber and Thompson, 2007). Nitrogen cycle in the soil-plant system is very dynamic and complex due to involvement of climatic, soil, and plant factors. Knowledge of the nutrient cycle in the soil-plant system is an important aspect of understanding the availability of $\mathrm{N}$ to plants and adopting management practices to maximize its uptake and use efficiency (Fageria and Baligar, 2005a).

The nitrogen cycle is the shift between different chemical forms of nitrogen through biologic, physical, and geologic processes on Earth. Nitrogen is an essential element for all living things. It is a building block of biologic molecules such as proteins and nucleic acids. The majority of nitrogen on the planet is in the form of molecular nitrogen in the air. Only certain bacteria can convert nitrogen into biologic molecules that occur mainly inside living cells. Humans are interfering with the nitrogen cycle by making nitrogen fertilizers and by oxidizing atmospheric molecular nitrogen through the extensive burning of fossil fuels. (Sergei A. Markov, 2015).

Legume-derived $\mathrm{N}$ from biological $\mathrm{N}_{2}$ fixation (BNF) is critical to the sustainability of organic crop (annual and perennial) production systems on commercial farms (Woodley et al., 2014), and contributes substantially to sustainability with respect to reduced energy use on organic farms (Lynch et al., 2011). However, productivity and nutrient $(\mathrm{N}$ and $\mathrm{P}$ ) loading and risk of losses, and nutrient use efficiency from organic production systems can vary with specific management practices and overall farm intensity of production; furthermore seasonal variation affects soil $\mathrm{N}$ mineralization and potential synchrony of soil available $\mathrm{N}$ supply with cash crop demand (Lynch et al., 2012a,b).

The consequences of human intervention in the nitrogen cycle include the obvious benefits for food security with approximately half of the global human population dependent on the increased yields of agricultural crops owing to fertilizer nitrogen usage, and substantially enhanced carbon sequestration resulting from $\mathrm{N}$ deposition to forests and other semi-natural terrestrial ecosystems (de Vries W et al. 2009).

The nitrogen applied in agriculture is derived from atmospheric sources, but unlike the natural process of $\mathrm{N}$ fixation, most agricultural $\mathrm{N}$ is fixed industrially by the Haber-Bosch process (Smil V. 2001), the remainder by nitrogen-fixing crops (Sprent IJ. 1987).

For instance, estimated $\mathrm{N}$ losses from arable land to be 31, 68, 112 and $27 \mathrm{~kg} \mathrm{ha}^{-1} \mathrm{yr}^{-1}$ in Zimbabwe, Malawi, 
Kisii, Kenya, and Tanzania, respectively (Stoorvogelet al. 1993)similar results have been found in Mali. In Niger, $\mathrm{N}$ losses of up to $91 \mathrm{~kg} \mathrm{ha}^{-1}$ have been attributed to leaching (Brouwer J, Powell JM., 1998)).

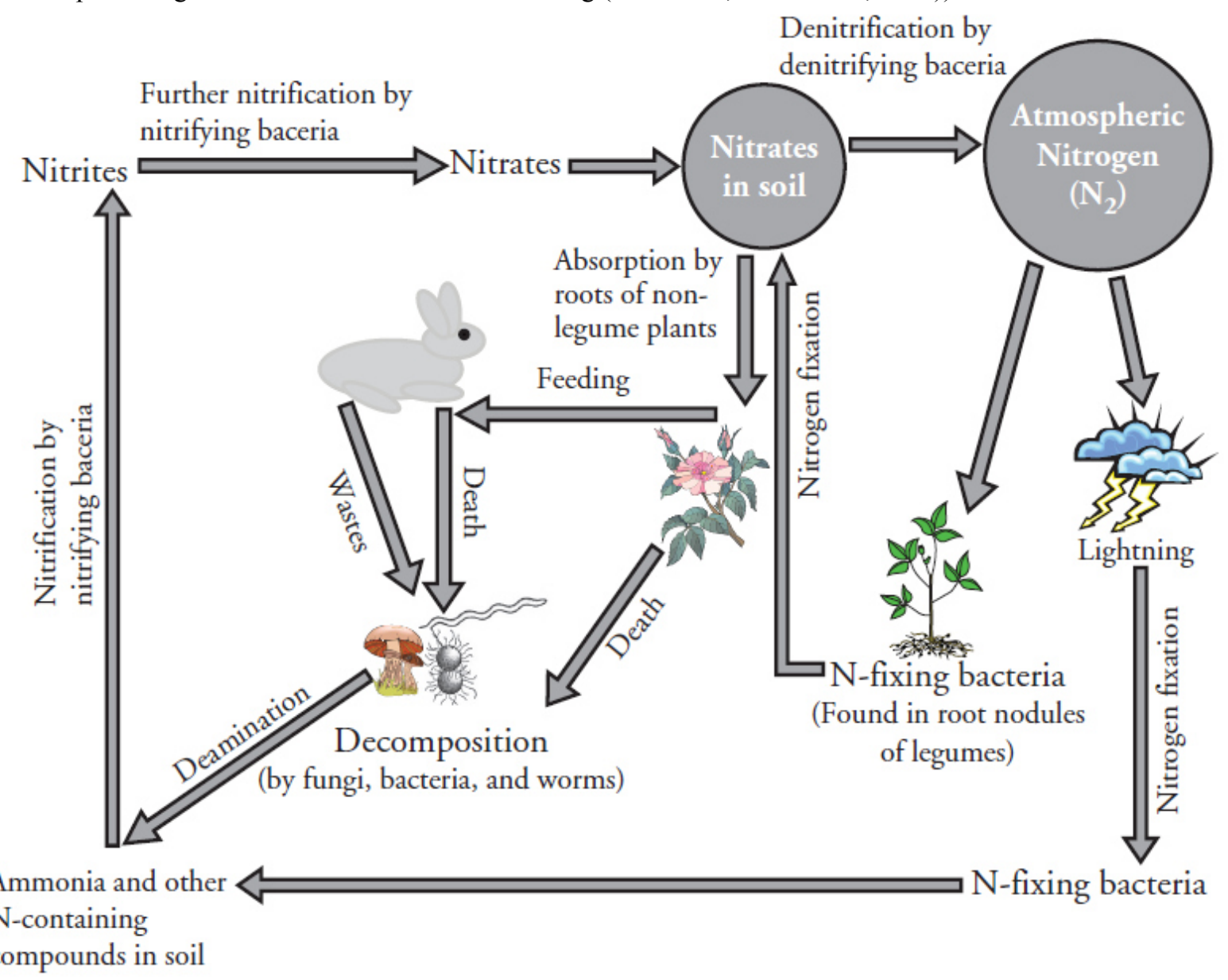

Figure 2: nitrogen cycle

Phosphorus $(\mathrm{P})$ is a naturally occurring element that can be found in the earth's crust, water, and all living organisms. Primarily phosphorus is available in a few minerals, the main of which is apatite. Weathering of the apatite parent rocks releases $\mathrm{P}$, this can be partially incorporated into the plant tissue and be transformed into an organic form (Filippelli, 2008)

Phosphorus (P) is a limiting nutrient for terrestrial biological productivity, and thus it commonly plays a key role in net carbon uptake in terrestrial ecosystems. Unlike nitrogen (another limiting nutrient but one with an abundant atmospheric pool), the availability of "new" $\mathrm{P}$ in ecosystems is restricted by its rate of release during soil weathering. The release of $\mathrm{P}$ places a limit on ecosystem productivity which in turn is critical to terrestrial carbon balances (Schlesinger, 1997).

Unlike nitrogen, which can be returned to the soil by fixation from the air, phosphorus cannot be replenished except from external sources once it leaves the soil in agricultural products or by erosion. Improving the efficiency and sustainability of $\mathrm{P}$ in the food system is currently based upon incremental adaptations to system management. An adapted food system can be considered as one where management has been altered to be more P efficient at the farm scale. Recycling is optimized as much as possible through integrated farming practices (Wezel, A, et al 2014), and P losses are managed by implementation of best management practices (Schoumans, O et al 2014).

Mixed crop-livestock farming, wider crop diversification and manure trading are examples of farm-scale adaptations which would stimulate $P$ minimization through $P$ recycling. Such recycling of bio-resources is a key 3R P stewardship strategy that benefits overall soil quality (Bhogal, A.et al2011), landscape biodiversity (Derner, $\mathrm{J}$ et al. 2009), and the resilience of farming systems, for example, to pest and disease attack or to commodity price fluctuations (Ryschawy, J et al2012). 


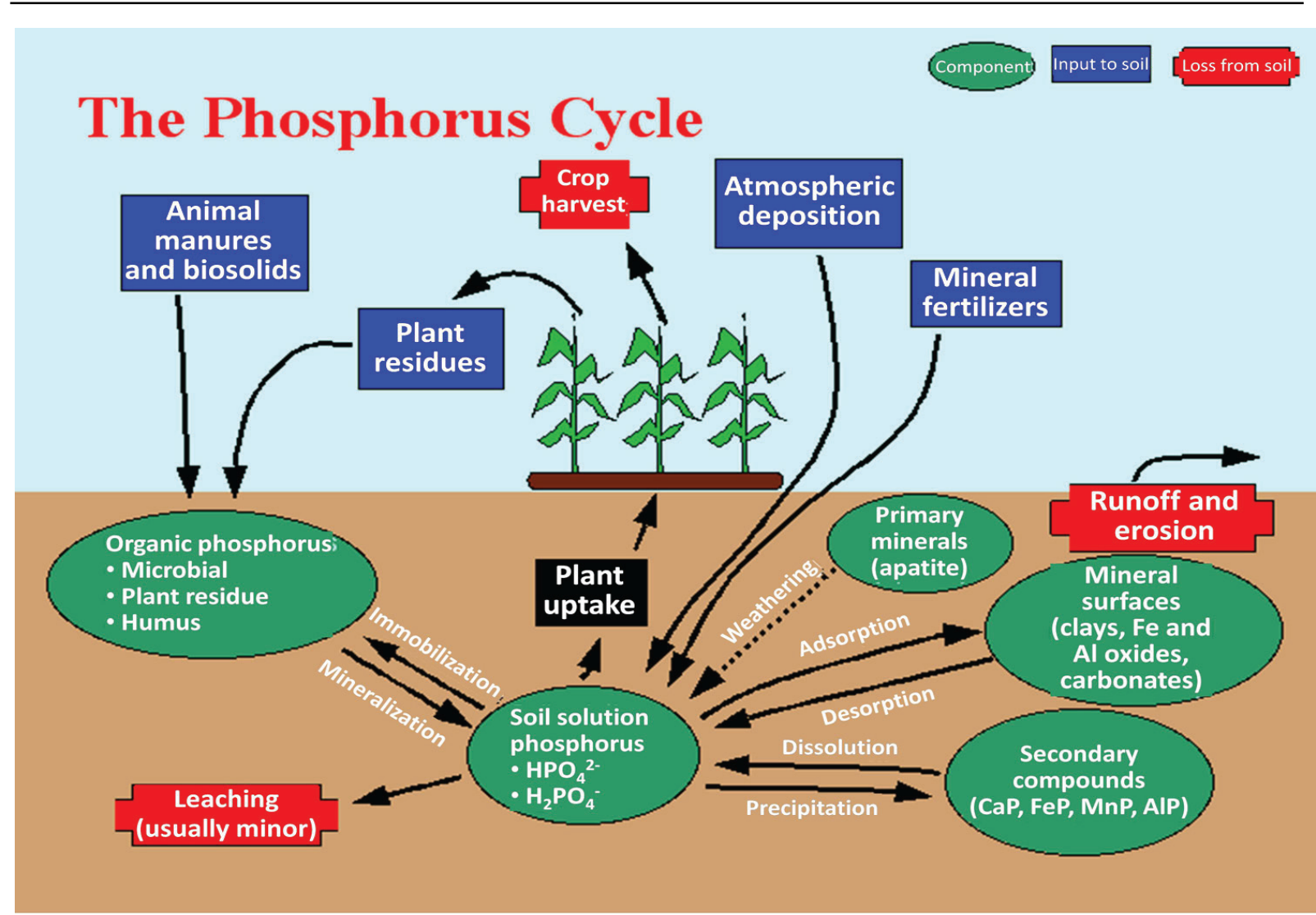

Figure 3: Phosphorus cycle

Potassium: As much $\mathrm{K}$ as $\mathrm{N}$ is taken up by many crops, so its supply is critical. Often, the ability of many soils to supply adequate amounts of $\mathrm{K}$ for many years leads to its under-application, and there are concerns that the UK and other countries are applying too little K (and P) owing to the need to save costs (Johnston et al. 2001). The supply of acceptable forms of $\mathrm{K}$ to organic systems is a particular problem (Watson et al. 2004).

Sulfur cycle is defined as the sequence of transformations undergone by sulfur wherein it is used by living organisms, transformed upon death and decomposition of the organisms, and ultimately converted to its original oxidation state (Soil Science Society of America 1997). Sulfur (S) has long been recognized as an essential element for plant growth and development and is classified as a macronutrient. Crop responses to applied sulfur have been reported in a wide range of soils in many parts of the world (Brady and Weil, 2002). Sulfur, an essential element for microorganisms and plants, is continuously being cycled between inorganic and organic forms (Castellano and Dick, 1990).

Table 1: Summary of Reactions for Nitrogen (N), Phosphorus (P), and Sulfur (S) Cycling

\begin{tabular}{|c|c|c|c|}
\hline Process/reaction & Reactant(s) & Product(s) & Mediator \\
\hline Assimilation & $\begin{array}{l}\mathrm{NO} ; \text { (nitrate), } \mathrm{NH}_{4}^{+} \text {(ammonium) } \\
\mathrm{PO}_{4}^{3-} \text { (phosphate), } \mathrm{SO}_{4}^{2-} \text { (sulfate) }\end{array}$ & Organic N. P, S & $\begin{array}{l}\text { Plants. fungi, } \\
\text { bacteria }\end{array}$ \\
\hline Mineralization & Organic $\mathrm{N}, \mathrm{P}, \mathrm{S}$ & $\begin{array}{l}\mathrm{NH}, \text { (ammonia), } \mathrm{NH}_{4}^{+} \\
\mathrm{PO}_{4}^{3-} \cdot \mathrm{S}^{2-} \text { (sulfide) }\end{array}$ & Bacteria, fungi \\
\hline Nitrification & $\mathrm{NH}$ : & $\mathrm{NO} ;$ (nitrite), $\mathrm{NO}$ & Bacteria \\
\hline Denitrification & $\mathrm{NO}$ & $\begin{array}{l}\mathrm{N}_{2}, \mathrm{~N}_{2} \mathrm{O} \text { (nitrous oxide), } \\
\text { NO (nitrogen oxide) }\end{array}$ & Bacteria \\
\hline Sulfate reduction & so:- & $\mathrm{H}_{2} \mathrm{~S}$ (hydrogen sulfide) & Bacteria \\
\hline Sulfide oxidation & $\mathrm{S}^{2-}$ & so:- & Bacteria \\
\hline Adsorption & $\begin{array}{l}\mathrm{NH} ; \mathrm{PO}_{4}^{3-} \\
\text { Organic } \mathrm{N}, \mathrm{P}, \mathrm{S}\end{array}$ & Sorbed forms & Abiotic \\
\hline Coprecipitation & $\mathrm{PO}_{4}^{3-}, \mathrm{S}^{2-}$ & $\begin{array}{l}\text { Amorphous } \mathrm{Fe} \text { (iron) and } \mathrm{Al} \\
\text { (aluminum) oxides, FeS (iron sulfide) }\end{array}$ & Abiotic \\
\hline
\end{tabular}

Source, Michael E McClain, 2014

Magnesium $\left(\mathrm{Mg}^{2+}\right)$ is an essential macronutrient for all plant growth and development. Its adequate level in 
the soil is important for producing maximum economic yields. Like deficiency of calcium $\left(\mathrm{Ca}^{2+}\right)$, deficiency of magnesium in crop production is more common on highly weathered acid soils (Fageria and Souza, 1991).

The cycle of $\mathrm{Mg}^{2+}$ in soil-plant systems involves its addition to soils and depletion by several processes. The main sources of $\mathrm{Mg}^{2+}$ addition are liming, $\mathrm{Mg}^{2+}$ fertilizers, crop residues, farmyard or green manures, and liberation by weathering of parent materials. Its removal or depletion from the soil-plant system is mainly through uptake by crops, soil erosion, and leaching. In addition, some part of $\mathrm{Mg}^{2+}$ is also fixed in the soil-plant system by soil colloids and microorganisms. Significant amounts of $\mathrm{Mg}^{2+}$ fixation in Oxisols and Ultisols when limed to $\mathrm{pH}$ above 7.0. Most of the $\mathrm{Mg}^{2+}$ is present in the soil as primary minerals, and very little exists in organic forms or in the form of organic complexes (Sumner et al. 1978; Grove et al. 1981).

Carbon cycle: Carbon (C) storage is an important ecosystem function of soils that has gained increasing attention in recent years. Changes in soil $\mathrm{C}$ impacts on, and feedbacks to, the Earth's climate system through emissions of $\mathrm{CO}_{2}$ and $\mathrm{CH}_{4}$ as well as storage of carbon removed from the atmosphere during photosynthesis and S.O.M itself also confers multiple benefits for human society by enhancing water purification and water holding capacity, protecting against erosion risk, and enhancing food and fiber provision through improved soil fertility (Pan et al., 2014).

Global $\mathrm{C}$ cycle is currently out of balance principally as a result of the burning of fossil fuels, but also due to the conversion of high $\mathrm{C}$-density natural ecosystems, such as forests and grasslands, to lower C-density agroecosystems. It should be noted that the $\mathrm{C}$ cycle has been perturbed by about $13 \%$ relative to its preindustrial state, compared with figures of $100 \%$ or more for the N, P, and S cycles (Falkowskiet al. 2000).

An increase in organic $\mathrm{C}$ is often accompanied by increased $\mathrm{N}$ resource use efficiency in croplands (Pan et al., 2009), especially when SOC is increased with biochar (Huang et al., 2013).

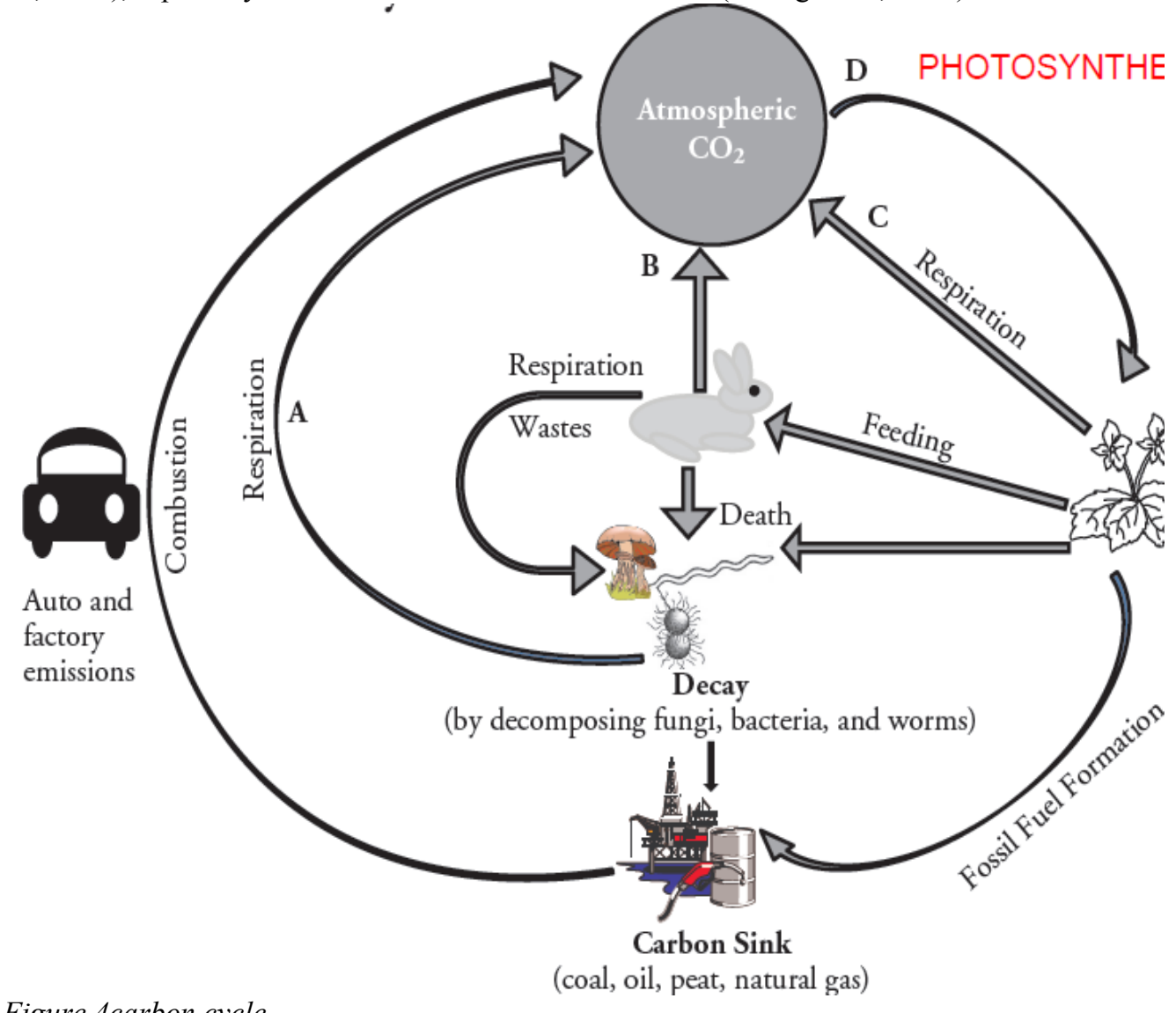

Figure 4carbon cycle

The availability of both macro- and micronutrients is influenced by soil chemical and physical properties. The soil nutrient content may not be always enough to fulfill crop requirement. Similarly, most of the micronutrients, for example $\mathrm{Fe}$ and $\mathrm{Mn}$ are readily fixed in soils having alkaline $\mathrm{pH}$ as carbonates and/or bicarbonate compounds. Plant roots are unable to absorb these nutrients adequately from dry topsoil (Graham et al., 1992; Foth and Ellis, 1997). Similarly, some nutrient elements, such as $\mathrm{Ca}, \mathrm{Mg}$ and $\mathrm{Mn}$ are not easily translocated to leaves within the plant system (Foth and Ellis, 1997).

Insufficient soil micronutrients are affecting both crop yield and reduce quality, and it is partly responsible for decreasing efficiency of N, P and K fertilizers. In rain fed areas, in spite of subsistence agriculture over a long period, soils are depleted not only major nutrients but also micro-and secondary nutrients (FAO, 2006). 


\section{Nutrient flows}

Soil nutrient flow is the amount of plants nutrients that flow in and out of a system. The difference between nutrient inflow (sum of nutrient inputs) and outflow (sum of nutrient outputs) is the nutrient balance (Nkonyaet al., 2004).

The presence of animals into the agricultural production system can modify the rates and flows, that is, the nutrient dynamics between the compartments of the system (Anghinoniet al., 2013). The net flow of $\mathrm{N}$ from the land into the oceans and the atmosphere is unsurprising given the mobility of $\mathrm{N}$ in soil water and transfer to the oceans by rivers and the advection of the atmospheric $\mathrm{N}$ by wind over coastlines (Billen $\mathrm{G}$ et al 2013).

There are increasing concerns about soil fertility and the risks of nutrient deficiencies in the crop production in extensive agricultural production systems, including a major proportion of organic farming systems. The limited scope for importing nutrients to organic farms can make balancing inflows against outflows difficult, which may result in nutrient imbalances and deficiencies (Watson et al., 2002).

Nutrient stocks flow and budgets are increasingly being used as tools for estimating nutrient build-up and decline so as to provide an understanding of the potential and suitability of land for agricultural production Partial balance approach has a shortcoming in that it excludes flows (e.g., $\mathrm{N}$ fixation, erosion) which could have high relative importance, especially in low external input agriculture (Janssen BH, 1999).

Nutrient flows and balances are currently and increasingly being used as powerful tools for estimating nutrient depletion or accumulation. The relevance of soil nutrient balances to agricultural potential of land has been emphasized by many scientists (Stoorvogelet al., 1993;

Smaling, 1993; Van den Bosch et al., 1998)

Nutrient output flows comprise removal of economic crop products and crop residues, leaching, gaseous losses, runoff and erosion. A situation where inputs exceed outputs is termed as surplus nutrient accumulation; when outputs exceed inputs, this is nutrient depletion. The concept of nutrient depletion is derived from quantifying nutrient flows resulting in nutrient balances and/or stocks (Vlaminget al., 2001).

$\mathrm{N}$ internal flows within a system include household waste feeds, crop residues, grazing of vegetation, and animal manure and farm products to a household. The potential supply of mineral-N by soil is determined by factors such as the mineralization-immobilization and N-loss mechanisms operating during the cropping season (Mtambanengwe F, Mapfumo P, 2006)

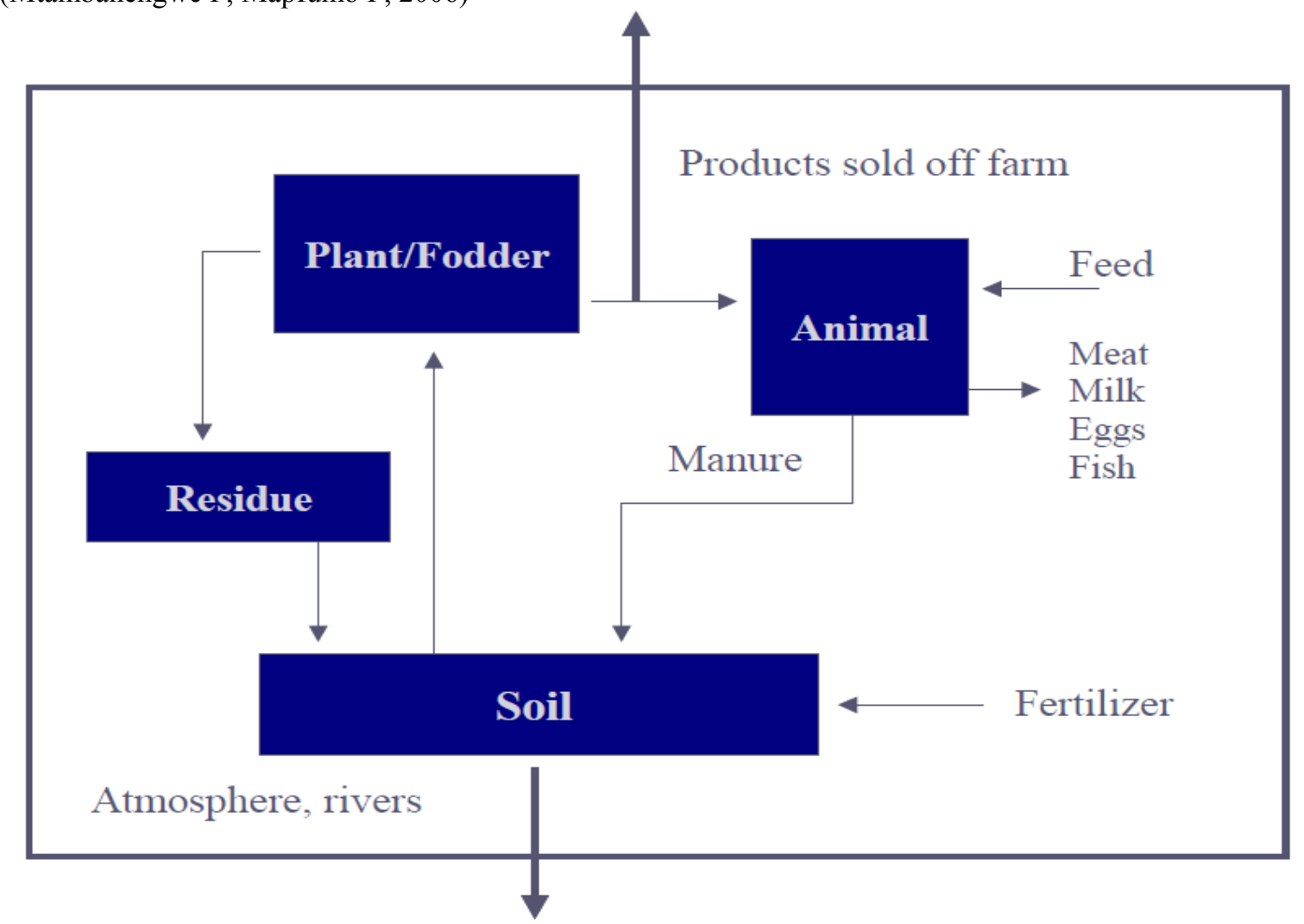

Figure 5: Nutrient Flows at the local Scale

Source, Ulrike Grote et al, 2014 


\section{Nutrient balance in different farming systems (NPK)}

Soil nutrient balances are a commonly used indicator and are defined as the difference between the sum of nutrient input flows and the sum of nutrient output flows within a specific system (field, farm, nation) over a certain period (season or year). Soil nutrient balances reflect the net change in soil fertility and indicate trends in time, but do not necessarily determine the current state of soil fertility. To determine the severity of the depletion rate, nutrient balances can be related to the soil nutrient stocks, where typically a depletion rate of more than $2 \%$ per year of the soil nutrient stock is considered unsustainable (Elias 2002).

Negative nutrient balances indicate that a system is losing nutrients; on the contrary, excess nutrient accumulation may lead to extended losses as a result of toxicities. The net difference between inputs and outputs of nutrients expressed in $\mathrm{kg}$ nutrients integrated over a certain area and time gives the net soil nutrient budget (Stoorvogel and Smaling, 1990).Balanced or equilibrium nutrient levels occur when inputs equals outputs. Hence, a summary of nutrient inputs and outputs from a defined system over a defined period of time is the nutrient budget for that spatio-temporal unit (Oenemaet al., 2003).

Nutrient budgets are important indicators of potential land degradation, for optimizing nutrient use, and designing policy to support improved soil fertility management by smallholder farmers and have been used extensively for improving natural resource management and/or for policy recommendations over the last decades (Grote et al., 2005).

Today there is an increasing need for a balanced fertilization strategy, minimizing the use of mineral fertilizers to enhance both crop production and quality and nutrient uptake under low input conditions (Murillo Amador et al 2015). Mineral fertilizers can be replaced by organic fertilizers (Szparaga, A.andKocira S.2018), plant bio stimulants (Alori, E et al 2018), and beneficial microbial inoculants (Fiorentino, N et al, 2018).

Regional and national estimates of $\mathrm{N}$ balances are negative in most of sub-Saharan Africa region. Numerous studies focusing on $\mathrm{N}$ balance, have consistently reported negative national averages which can be ascribed to the several $\mathrm{N}$ losses channels especially through harvest, soil erosion and low or non-use of external soil inputs (Milka N., 2019). For Africa as a whole, low level of inputs relative to outputs results in a consistently negative balance (Stoorvogelet al., 1993).

Element balance calculations at farm/field level can be a tool for evaluation of different farming systems from an environmental perspective (risks for emissions from agriculture) and a sustainable nutrient management perspective (Öbornet al., 2003). Balances of both nutrients and trace metals for different types of agricultural systems can be used to gain insights into the long-term development of soil quality and sustainability of the system. The balance calculation tool has become widely used by policy-makers, extension workers (advisors), certification organizations and farmers as an instrument for planning and control of on-farm nutrient management directed towards more sustainable agricultural production (Goodlasset al., 2003).

$\mathrm{N}$ balances in most wealthy farms were positive while those for medium and poor farms were close to zero or negative. Apart from the assumption that fields near the homesteads are zones of nutrient accumulation and distant fields are zones of depletion, $\mathrm{N}$ balances also depend on the value of the crop grown as perceived by the farmers and the intensity of soil management practices (Giller KE, et al 2006, Tittonell PA ,2007). At crop level higher inflows of both inorganic and organic fertilizers for maize compared with groundnut, as farmers invariably applied more fertilizers to maize crops with little or nothing to the groundnuts As a consequence, $\mathrm{N}$ balances were mostly positive for maize and negative for groundnuts (Zingoreet al., 2000).

In assessing nutrient depletion through use of nutrient balances at any given time, a number of inputs and outputs are considered. Nutrient input processes are: application of mineral fertilizer and organic manure, atmospheric deposition, Biological $\mathrm{N}_{2}$ fixation and sedimentation by irrigation and flooding. Even though a number of nutrient flows can easily be quantified and valued in monetary terms based on the input and output processes (partial balance), other flows are hard to quantify hence often estimated on the basis of transfer functions, for instance those developed for sub-Saharan Africa by (Stoorvogelet al., 1993), adopted and critically reviewed by others Scoones and Toulmin, 1998; FAO, 2003). A partial nutrient balance considers direct nutrient inflows from mineral fertilizers and organic materials and outflows resulting from harvested products and crop residues (Harris, 1998) 
Table 2: Average Nutrient Balances for Selected Sub-Saharan African Countries

\begin{tabular}{|c|c|c|c|c|c|c|}
\hline \multirow[t]{3}{*}{ Country } & \multicolumn{2}{|c|}{$\mathrm{N}$} & \multicolumn{2}{|c|}{$\mathrm{P}$} & \multicolumn{2}{|c|}{$\mathrm{K}$} \\
\hline & $1982-84$ & 2000 & $1982-84$ & 2000 & $1982-84$ & 2000 \\
\hline & \multicolumn{6}{|c|}{$\mathrm{kg} / \mathrm{ha} /$ year } \\
\hline Benin & -14 & -16 & -1 & -2 & -9 & -11 \\
\hline Botswana & o & -2 & 1 & o & o & -2 \\
\hline Cameroon & -20 & -21 & -2 & -2 & -12 & -13 \\
\hline Ethiopia & -41 & -47 & -6 & -7 & -26 & -32 \\
\hline Ghana & -30 & -35 & -3 & -4 & -17 & -20 \\
\hline Kenya & -42 & -46 & -3 & -1 & -29 & -36 \\
\hline Malawi & -68 & -67 & -10 & -10 & -44 & -48 \\
\hline Mali & -8 & -11 & -1 & -2 & -7 & -10 \\
\hline Nigeria & -34 & -37 & -4 & -4 & -24 & -31 \\
\hline Rwanda & -54 & -60 & -9 & -11 & -47 & -61 \\
\hline Senegal & -12 & -16 & -2 & -2 & -10 & -14 \\
\hline Tanzania & -27 & -32 & -4 & -5 & -18 & -21 \\
\hline Zimbabwe & -31 & -27 & -2 & 2 & -22 & -26 \\
\hline
\end{tabular}

Source: Roy et al., 2003

Ethiopia is considered as one of the most vulnerable countries in sub-Sahara Africa (SSA) with regard to soil fertility depletion because of its mountainous topography and intensive farming systems based on small cereals. Indeed, national averages of nutrient balances were estimated at $-41 \mathrm{~kg} \mathrm{~N},-6 \mathrm{~kg} \mathrm{P}$ and $-26 \mathrm{~kg} \mathrm{~K}$ per ha per year, which is among the highest nutrient depletion rates for sub-Saharan Africa (Stoorvogel and Smaling 1993). Yet, soil nutrient balances can differ considerably between different crops, farming systems and agroecological zones (Sommeret al. 2014).

The nutrient input flows and output flows were monitored over a period of 3 years (2012-2014) using the monitoring for quality improvement toolbox. Average nitrogen $(\mathrm{N})$, phosphorus $(\mathrm{P})$ and potassium $(\mathrm{K})$ balances were $-23 \pm 73,9 \pm 29$ and $-7 \pm 64 \mathrm{~kg} \mathrm{ha}^{-1}$, respectively. (C. L. van Beeket al. 2016).

Table 3: Nutrient balances of CASCAPE and previously reported values for Ethiopia $\left(\mathrm{kg} \mathrm{ha}^{-1}\right)$

\begin{tabular}{|l|l|l|l|l|l|}
\hline & References & Farming system & N & P & K \\
\hline 1 & C. L. van Beeket al. 2016 & Mixed, smallholder & -24 & 9 & -7 \\
\hline 2 & Stoorvogel and Smaling (1993) & National level & -47 & -7 & -32 \\
\hline 3 & Elias (1998); Atichoet al. (2011) & Enset_coffee (Wolaita) & $? 3$ & +5 & n.d. \\
\hline 4 & Haileslassieet al. (2006) & Cereal (Central Ethiopia) & -50 & -4 & -64 \\
\hline 5 & Haileslassieet al. (2006) & Enset (Guraghe highlands) & +68 & +7 & -23 \\
\hline 6 & Haileslassieet al. (2006) & Cereal (western Ethiopia) & -46 & $? 3$ & -75 \\
\hline 7 & Asefaet al. (2003) & Low potential Tigray (Atsbi) & -65 & -6 & -34 \\
\hline 8 & Elias (2002) & National average & -92 & $? 5$ & -49 \\
\hline
\end{tabular}

n.d.= no data

Source: NutrCyclAgroecosyst (2016)

\section{Summery and conclusion}

Soil fertility management is continuously modified and adapted as conditions change in time and integrated plant nutrient management is a holistic approach to optimizing plant nutrient supply for the objective of adequately nourish the crop as efficiently as possible, while minimizing potentially adverse impacts to the environment. Nutrients cycles have been substantially altered by human activities mainly agriculture over the past two centuries with large positive and negative consequences for a range of ecosystem services and for human wellbeing. Ecosystems regulate the flows and concentrations of nutrients through a number of complex processes including a diversity of species.

Integrated crop-livestock systems can positively change the biophysical and socio-economic dynamics of 
farming systems, reestablishing sustainable rural development and promoting higher overall farm profitability to maximize production of crops and livestock on the same area, concurrently or sequentially in rotation or succession

Organic matter plays several pivotal roles in determining nutrient availability to plants. Since uptake by plants is almost exclusively in the inorganic form, the biologically mediated process of organic matter decomposition is crucial to nutrient availability

Many farming systems still rely on natural release of nutrients from the soil through mineralization and approximately $60-80 \%$ of the farm income was obtained at the expense of soil nutrient depletion. Soil tests are designed to help farmers predict the available nutrient status of their soils. Once the existing nutrient levels are established, producers can use the data to best manage what nutrients are applied, decide the application rate and make decisions concerning the profitability of their operations

In Ethiopia, low-input agricultural production systems and poor agronomic management practices, limited awareness of communities and absence of proper land-use policies have aggravated soil fertility degradation. This has also encouraged the expansion of farming to marginal, non-cultivable lands, including steep landscapes and range lands. Soil nutrient balances can differ considerably between different crops, farming systems and agro-ecological zones. For example, +68 and -46 for nitrogen, +7 and +3 for $\mathrm{P},-23$ and -75 for K on Enset and on cereal respectively

\section{Prospects}

$\checkmark \quad$ Limited use of nutrient inputs among smallholder farmers exacerbates soil nutrient deficiency.

$\checkmark \quad$ African fertilizer use was never high, averaging about $9 \mathrm{~kg}$ per hectare

$\checkmark$ The estimated losses, due to erosion, leaching, and crop harvests are sometimes staggering, at over $60-$ $100 \mathrm{~kg}$ of N, P, and K per hectare each year in Western and Eastern Africa

$\checkmark$ SSA's depleted soils; production cannot be increased without bringing to the farm nutrients from outside either through livestock manure or mineral fertilizer

\section{Acknowledgment}

First of all, I would like to thank almighty God he gave patience to encourage the ups and down during my everyday life and enable me to do my work. I would like to express my deepest gratitude and thanks to my wife Yeti work Mamo because she help me to prepare this review.

$\begin{array}{ll}\text { Abbreviation } \\ \text { AV } & \text { accommodation value } \\ \text { BNF } & \text { biological } \mathrm{N}_{2} \text { fixation } \\ \text { FV } & \text { fertilizer value } \\ \text { IPNM } & \text { Integrated plant nutrient management } \\ \text { NUE } & \text { Nitrogen use efficiency } \\ \text { OM } & \text { organic matter } \\ \text { PSM } & \text { phosphate-solubilizing microorganisms } \\ \text { RV } & \text { recovery value } \\ \text { SOC } & \text { soil organic carbon } \\ \text { SOM } & \text { soil organic matter }\end{array}$

\section{References}

Aguinaga AAQ, Carvalho PCF, Anguinoni I, Pilau A, Aguinaga AJQ, Gianluppi GDF 2008. Morphological components and forage production of oat (Avenastrigosa, Schreb) and annual ryegrass (Loliummultiflorum, Lam) pasture managed at different heights. R Bras Zootec. 37(9): 1523-1530.

Alori, E.T. and Babalola, O.O., 2018. Microbial inoculants for improving crop quality and human health in Africa. Frontiers in Microbiology, 9, p.2213

Barea, J.M., 1997. Azcón-Aguilar C and Azcón R, Interactions between mycorrhizal fungi and rhizosphere microorganisms within the context of sustainable soil-plant systems Multitrophic Interactions in Terrestrial Systems, pp.65-77

Batista, I., Correia, M.E.F., Pereira, M.G., Bieluczyk, W., Schiavo, J.A. and Rouws, J.R.C., 2014. Oxidizable fractions of total organic carbon and soil macrofauna in a crop-livestock integration system RevistaBrasileira de Ciência do Solo, 38(3), pp.797-809.

Beusen, A.H.W., Bouwman, A.F., Heuberger, P.S.C., Van Drecht, G. and Van Der Hoek, K.W., 2008. Bottomup uncertainty estimates of global ammonia emissions from global agricultural production systems. Atmospheric Environment, 42(24), pp.6067-6077

Bhogal, A., Nicholson, F.A., Young, I., Sturrock, C., Whitmore, A.P. and Chambers, B.J., 2011. Effects of 
recent and accumulated livestock manure carbon additions on soil fertility and quality. European journal of soil science, 62(1), pp.174-181

Billen, G., Garnier, J. and Lassaletta, L., 2013. The nitrogen cascade from agricultural soils to the sea: modelling nitrogen transfers at regional watershed and global scales. Philosophical Transactions of the Royal Society B: Biological Sciences, 368(1621), p.20130123.

Boesen, J. and Friis-Hansen, E., 2001. Soil fertility management in semi-arid agriculture in Tanzania: farmers' perceptions and management practices (Vol. 1). Centre for Development Research.

Brady, N. and Weil, R.R., 2002. The nature and properties of soils.13 Edic. Prentince Hall. New Jersey. USA. 598 p.

Brouwer, J. and Powell, J.M., 1998. Increasing nutrient use efficiency in West-African agriculture: the impact of micro-topography on nutrient leaching from cattle and sheep manure Agriculture, ecosystems \& environment, 71(1-3), 229-239

C. L. van Beek . E. Elias . G. S. Yihenew .H. Heesmans . A. Tsegaye . H. Feyisa . M. Tolla . M. Melmuye .Y. Gebremeskel. S. Mengist 2016. Soil nutrient balances under diverse agro-ecological settings in Ethiopia.,NutrCyclAgroecosyst 106:257-274

Castellano, S. D. and R. P. Dick. 1990. Cropping and sulfur fertilization influence on sulfur transformations in soil. Soil Sci. Soc. Am. J. 54:114-121.

Christensen, B. T. 2004. Tightening the nitrogen cycle. In: Schjønning, P., Elmholt, S. and Christensen, B. T. (eds.) Managing Soil Quality: Challenges in Modern Agriculture , CAB International, Wallingford, UK, pp. 47-67.

Cordell D, Drangert J-O, White S 2009. The story of phosphorus: global food security and food

for thought. Glob Environ Chang 19(2):292-305

Cobo JG, Dercon G, Cadisch G 2010. Nutrient balances in African land use systems across different spatial scales: A review of approaches, challenges and progress. AgricEcosyst Environ 136: 1-15.

Crews, T. E. and Peoples , M. B. 2005. Can the synchrony of nitrogen supply and crop demand be improved in legume and fertilizer-based agro-ecosystems? A review.Nutrient Cycling in Agro ecosystems, 72, 101 -129

Dalsgaard, J.P.T. and R.T. Oficial. 1997. A quantitative approach for assessing the productive performance and ecological contributions of smallholder farms. Agric. Syst. 55, 503-533.

deJager A, Onduru DD, van Wijk MS, Vlaming J, Gachini GN 2001. Assessing sustainability of low-externalinput farm management systems with the nutrient monitoring approach: a case study in KenyaAgricSyst 69:99-118

De Vries W et al. 2009. The impact of nitrogen deposition on carbon sequestration by European forests and heathlandsForest Ecol. Manag. 258, 1814-1823.

Derner, J.D.; Lauenroth, W.K.; Stapp, P.; Augustine, D.J. 2009 Livestock as ecosystem engineers for grassland bird habitat in the western Great Plains of North America. Rangel. Ecol. Manag., 62, 111-118.

Donovan, G. \& Casey, H., 1998.Soil fertility management in sub-Saharan Africa. World Bank, Technical Paper No. 408, Washington, D.C

Elias E 2002.Farmer's perceptions of soil fertility change and management SOS-Sahel and Institute for Sustainable Development. Addis Ababa, pp 252

Entz MH, Bellotti WD, Powell JM 2005. Evolution of integrated crop-livestock production systemsIn:McGilloway DA et al (eds) Grassland: a global resource. Wageningen Academic Publishers, the Netherlands, pp 137-148

Fageria, N. K. and C. M. R. Souza. 1991. Upland rice, common bean, and cowpea response to magnesium application on an Oxisol. Commun.Soil Sci. Plant Anal. 22:1805-1816.

Fageria, N. K. and V. C. Baligar. 1997. Response of common bean, upland rice, corn, wheat, and soybean to fertility of an Oxisol. J. Plant Nutr. 20:1279-1289.

Fageria, N. K. and V. C. Baligar. 2005a. Enhancing nitrogen use efficiency in crop plants. Adv. Agron. 88:97185.

Falkowski, P., R.J. Scholes, E. Boyle, J. Canadell, D. Canfield,., 2000: The global C cycle: A test of our knowledge of Earth as a system. Science290, 291-296

Roy, R.N., Misra, R.V., Lesschen, J.P. and Smaling, E.M.A., 2003. Assessment of soil nutrient balance: approaches and methodologies (No. 14). Food \& Agriculture Org..

Bot, A. and Benites, J., 2005. The importance of soil organic matter: Key to drought-resistant soil and sustained food production (No. 80). Food \& Agriculture Org.

Fairhurst, T. (ed.) 2012.Handbook for Integrated Soil Fertility Management. Africa Soil Health Consortium, Nairobi.

Filippelli GM 2008. The global phosphorus cycle: past, present, and future. Elements 4(2):89-95

Fiorentino, N., Ventorino, V., Woo, S.L., Pepe, O., De Rosa, A., Gioia, L., Romano, I., Lombardi, N., Napolitano, M., Colla, G. and Rouphael, Y., 2018. Trichoderma-based biostimulants modulate rhizosphere 
microbial populations and improve $\mathrm{N}$ uptake efficiency, yield, and nutritional quality of leafy vegetables. Frontiers in plant science, $9, .743$

Foth HD and BG Ellis. 1997. .Soil fertility, 2nd Edition Lewis CRC Press LLC., USA.

GrahamRD, JS Ascher, and SC Hynes .1992.Selecting zinc-efficient genotypes for soils of low zinc status.Plant and Soil. 146: 241-250.

Galloway J.N., F.J. Dentener, D.G. Capone, E.W. Boyer, R.W. Howarth, S.P. Seitzinger, G.P. Asner, C.C. Cleveland, P.A. Green, E.A. Holland, D.M. Karl, A.F. Michaels, J.H. Porter, A.R. Townsend and C.J. VO“ RO“ Smarty 2004. Nitrogen cycles: past, present, and future. Biogeochemistry 70: 153-226

GetachewAgegnehu and TayeBekele. 2005. On-farm integrated soil fertility management in wheat on Nitisols of central Ethiopian highlands. EthiopianJournal of Natural Resources7: 141-155.

Agegnehu, G. and Amede, T., 2017. Integrated soil fertility and plant nutrient management in tropical agroecosystems: a review. Pedosphere, 27(4),.662-680.

Getachew, Agenehu, Berhane, Lakew and N.N. Paul 2014.Cropping sequence and nitrogen fertilizer effects on the productivity and quality of malting barley and soil fertility in the Ethiopian highlands. Archives of Agronomy and Soil Science. 60 (9): 1261-1275.

Zelleke, G., Agegnehu, G., Abera, D. and Rashid, S., 2010. Fertilizer and soil fertility potential in Ethiopia. Constraints and opportunities for enhancing the system. IFPRI, Addis Ababa, Ethiopia, 42

Giller KE, Rowe E, De Ridder N, 2006. Resource use dynamics and interactions in the tropics: scaling up in space and time. AgricSyst88: 8-27.

GirmaChala. 2016. Soil test phosphorous calibration for potato production on Nitisols of central highlands Ethiopia.Ethiop. J. Sci. Sus. Dev. 120-137.

Goodlass, G., Halberg, N. \&Verschuur, G., 2003. Input Output Accounting Systems in the European Community - an appraisal of their usefulness in raising awareness of environmental problems. European Journal of Agronomy 20, 17-24.

Goulding, K. W. T. 2000 Nitrate leaching from arable and horticultural land. Soil Use Manage. 16, $145-151$.

Griffon, M. 2006. Feeding the Planet For a Doubly Green Revolution. Paris: Odile Jacob.

Grote, U., Craswell, E. \&Vlek, P. 2005. Nutrient flows in international trade: ecology and policy issues, Environmental Science and Policy, 8,439-451.

Grove, J. H., M. E. Sumner, and J. K. Syers. 1981. Effect of lime on exchangeable magnesium in variable surface charge soils. Soil Sci. Soc. Am. J. 45:497-500.

Gyaneshwar, P., Kumar, G.N., Parekh, L.J. and Poole, P.S. 2002.Role of soil microorganisms in improving P nutrition of plants.Plant and Soil245: 83-93.

Harris, F.M.A. 1998. Farm-level assessment of nutrient balance in northern NigeriaAgriculture,Ecosystems and Environment, 71:201-214

Hengl T, Heuvelink GBM, Kempen B, 2015. Mapping soil properties of Africa at $250 \mathrm{~m}$ resolution: Random forests significantly improve current predictions. PLOS ONE, 10:1-26.

Hentz P, Carvalho NL, Luz LV, Barcellos AL 2014. Nitrogen cycling in crop-livestock systems. Ciência $e$ Natura. 36: 663-676.

Hou Y, Velthof GL, Lesschen JP, Staritsky IG, Oenema O 2017 Nutrient recovery and emissions of ammonia, nitrous oxide, and methane from animal manure in Europe: effects of manure treatment technologies. Environmental Science \&Technology51, 375-383.

IFA 2009 The global '4R' nutrient stewardship framework. International Fertilizer Industry Association, Paris, p 10

Janssen BH 1999. Basics of budgets, buffers and balances of nutrients in relation to sustainability of agroecosystemsIn: Smaling EMA, Oenema O, Fresco LO, (Eds.), Nutrient disequilibria in agroecosystemsconcepts and case studies, CAB International, Wallingford, Oxon, UK, 27-56.

Johnston, A. E., Goulding, K. W. T., Poulton, P. R. \& Chalmers, A. 2001 Reducingfertiliser inputs: endangering arable soil fertility? In Proc. no 487, International Fertiliser Society, pp. 44. York, UK: International Fertiliser Society.

Keulen, H.V. and Schiere, H., 2004. Crop-livestock systems: old wine in new bottles?.In " New Directions for a Diverse Planet", 4th International Crop Science Congress in conjunction with the 12th Australian Agronomy Conference and the 5th Asian Crop Science Conference, 26 September-1 October 2004, Brisbane, Australia. Australian Society of Agronomy Inc

Lavelle, P. and A.V. Spain, 2001.Soil Ecology, Kluwer Scientific Publications, Amsterdam, p 691

Lynch, D. H., Halberg, N., \&Bhatta, G. D. 2012a.. Environmental impacts of organic agriculture in temperate regions. CAB Reviews, 7, 1-17.

Lynch, D. H., MacRae, R. J., \& Martin, R. C. 2011.The carbon and global warming potential impacts of organic farming: Does it have a significant role in an energy constrained world? Sustainability, 3, 322-362.

Lynch, D. H., Sharifi, M., Hammermeister, A., \& Burton, D. 2012b Nitrogen Management in Organic Potato 
Production. In: H. Zhongi, R. P. Larkin \& C. W. Honeycutt (Eds.), Sustainable Potato Production: GlobalCase Studies. 209-231)

Mando, A., and R. Miedema, 1997: Termite-induced change in soil structure after mulching degraded soil in the Sahel. Appl SoilEcol6:241-249.

Mengel, K., Kirkby, E.A., Kosegarten, H. and Appel, T., 2001.Nitrogen. In Principles of plant nutrition pp. $397-$ 434

Milka N. Kiboi1,*, Felix K. Ngetich1and Daniel N. Mugendi2 2019.Nitrogen budgets and flows in African smallholder farming systems AIMS Agriculture and Food, 4(2): 429-446.

Millennium Ecosystem Assessment.2005a. Ecosystems and human well-being Vol. I: Current state and trends. Washington, DC: Island Press.

Moraes AD, Carvalho PCDF, Lustosa SBC, Lang CR, Deiss L 2014. Research on integrated crop-livestock systems in Brazil.RevistaCiênciaAgronômica 45(5SPE):1024-1031

Mtambanengwe F, Mapfumo P 2006. Effects of organic resource quality on soil profile N dynamics and maize yields on sandy soils in Zimbabwe. Plant Soil281: 173-191.

Mtambanengwe F, Mapfumo P (2006) Effects of organic resource quality on soil profile N dynamics and maize yields on sandy soils in Zimbabwe. Plant Soil281: 173-191.

Murillo - Amador, B.; Morales - Prado, L.E.; Troyo - Diéguez, E.; Córdoba - Matson, M.V.; Hernández Montiel, L.G.; Rueda - Puente, E.O.; Nieto - Garibay, A. Changing environmental conditions and applying organic fertilizers in OriganumvulgareL. Front. Plant Sci. 2015, 6, 549

Nkonya, E. ed., 2004. Strategies for sustainable land management and poverty reduction in Uganda (Vol. 133). Intl Food Policy Res Inst.

Öborn, I., Edwards, E., Witter, E., Oenema, O., Ivarsson, K., Withers, P.J.A., Nilsson, S.I. \&RichertStinzing, A. 2003. Element balances as a tool for sustainable nutrient management: a critical appraisal of their merits and limitations within an agronomic and environmental context. European Journal of Agronomy 20, 211225.

Oenema, O.,Oudendag, D. and Velthof, G. L. 2007). Nutrient losses from manure management in the European Union. Livestock Science, 112, $261-272$

Oenema, O., Kros, H. \& de Vries, W. 2003. Approaches and uncertainties in nutrient budgets: implications for nutrient management and environmental policies. 20. European Journal of Agronomy, 20,3-16.

Pagani A, Sawyer JE, Mallarino AP 2013 Site-specific nutrient management for nutrient management planning to improve crop production, environmental quality, and economic return. Iowa State University, International Plant Nutrition Institute, The Fertilizer Institute and Nutrient, USDA-NRCS

Parton W. J., J.W.B. Stewart, and C.V. Cole, 1988: Dynamics of C, N, P and S in grasslands soils: a model. Biogeochemistry5:109-131.

Richardson, A.E., J.P. Lynch, P.R. Ryan, E. Delhaize, F.A. Smith,S.E. Smith, P.R. Harvey, M.H. Ryan, et al. 2011. Plant and microbial strategies to improve the phosphorus efficiency of agriculturePlant and Soil 349: $121-156$.

Roy, R.N., Finck, A., Blair, G.J. and Tandon, H.L.S., 2006. Plant nutrition for food security. A guide for integrated nutrient management. FAO Fertilizer and Plant Nutrition Bulletin, 16, p.368

Rong X. M., J.J. Rong, and Z.H. Mei, 2001.Effects of application inorganic fertilizer in combination with organic fertilizer to red upland soil.J. Hunan Agric. Univ., 27: 453-456.

Russelle MP, Entz M, Franzluebbers AJ 2007. Reconsidering integrated crop-livestock systems in North America. Agron J 99:323-324

Ryschawy, J.; Choisis, N.; Choisis, J.P.; Joannon, A.; Gibon, A. 2012.Mixed crop-livestock systems: An economic and environmental-friendly way of farming? Animal, 6, 1722-1730.

Schlesinger, W.H., 1997. Biogeochemistry: An Analysis of Global Change. San Diego, USA: Academic Press, $588 \mathrm{pp}$.

Schoumans, O.F.; Chardon,W.J.; Bechmann, M.; Gascuel-Odoux, C.; Hofman, G.; Kronvang, B.; Rubæk, G.H.; Ulén, B.; Dorioz, J.-M. 2014. Mitigation options to reduce phosphorus losses the agricultural sector and improve surface water quality: A review. Sci. Total Environ. 468-469, 1255-1266.

Schröder JJ, Smit AL, Cordell D, Rosemarin A 2011. Improved phosphorus use efficiency in agriculture: a key requirement for its sustainable use. Chemosphere 84(6):822-831

Scoones, I. \&Toulmin, C. 1998.. Soil nutrient balances: What use for policy? Agriculture, Ecosystems \& Environment, 71,255-267

Sergei A. Markov, 2015.Nitrogen cycle.pp. 347-348. In: Advances in Biochemical Engineering/ Biotechnology (eds): Earth's Weather, Water, and Atmosphere, Austin Peay State University.

Smil V. 2001 Enriching the earth. Fritz Haber, Carl Bosch, and the transformation of world food production. Cambridge, MA: The MIT Press.

Sommer R, Thierfelder C, Tittonell P, Hove L, Mureithi J, Mkomwa S 2014. Fertilizer use should not be a fourth 
principle to define conservation agriculture Response to the opinion paper of Vanlauwe et al. (2014) A fourth principle is required to define conservation agriculture in sub-Saharan Africa: the appropriate use of fertilizer to enhance crop productivity. Fields Crops Res 169:145-148

Sprent IJ. 1987 The Ecology of the nitrogen cycle. Cambridge, UK: Cambridge University Press.

Strokal, M., Ma, L., Bai, Z., Luan, S., Kroeze, C., Oenema, O., Velthof, G. and Zhang, F., 2016.Alarming nutrient pollution of Chinese rivers as a result of agricultural transitions. Environmental Research Letters, 11(2), p.024014.

Drechsel, P., Gyiele, L., Kunze, D. and Cofie, O., 2001. Population density, soil nutrient depletion, and economic growth in sub-Saharan Africa. Ecological economics, 38(2), pp.251-258.

Stoorvogel JJ, Smaling EMA 1990.Assessment of soil nutrient depletion in Sub-Saharan Africa, 1983-2000. Rep. 28, Winand Staring Centre, Wageningen, p137

Stoorvogel, J.J., Smaling, E.M.A. \& Janssen, B.H. 1993. Calculating soil nutrient balances at different scale. I. Supra-national scale. Fertilizer Research, 35,227-235

Sumner, M. E., P. M. W. Farina, and V. J. Hurst. 1978. Magnesium fixation: A possible cause of negative yield responses to lime applications. Commun.Soil Sci. Plant Anal. 9:995-1008.

Sutton MA, Bleeker A, Howard CM, Bekunda M, Grizzetti B, de Vries W, van Grinsven HJM, Abrol YP, Adhya TK, Billen G, Davidson EA, Datta A, Diaz R, Erisman JW, Liu XJ, Oenema O, Palm C, Raghuram N, Reis S, Scholz RW, Sims T, Westhoek H, Zhang FS 2013 'Our nutrient world: the challenge to produce more food and energy with less pollution'. (NERC/Centre for Ecology \& Hydrology: Edinburgh)

Szparaga, A.; Kocira, S. 2018.Generalized logistic functions in modeling emergence of Brassica napusL. PLOSONE,p13

Tarafdar, J.C. and Claassen, N. 1988. Organic phosphorus compounds as a phosphorus source for higher plants through the activity of phosphatases produced by plant roots and microorganisms. Biology and Fertilityof Soils5: 308-12.

Thornton, P.K. and M. Herrero. 2001. Integrated crop-livestock simulation models for scenario analysis and impact assessment. Agric. Syst. 70, 581-602.

Tilman, D., Cassman, K.G., Matson, P.A., Naylor, R., Polasky, S. 2002. Agricultural sustainability and intensive production practices. Nature 418,671-677

Tinker, P. B. 2000.Shades of green.A review of UK farming systems. National Agricultural Centre: Royal Agricultural Society of England.

Tittonell PA 2007MsimuwaKupanda : Targeting resources within diverse, heterogeneous and dynamic farming systems of East Africa. Thesis (Ph.D.).Wageningen University, Wageningen, NL, 320

Van den Bosch H, Jager AD, Vlaming J 1998. Monitoring nutrient flows and economic performance in African farming systems (NUTMON) - II. Tool development.AgricEcosyst Environ 71: 49-62.

Vanlauwe, B., A. Bationo, J. Chianu, K.E. Giller, R. Merckx, U. Mokwunye, O. Ohiokpehai, P. Pypers, R. Tabo, K.D. Shepherd, M.A. Smaling, P.L. Woomer, and N. Sanginga, N. 2010. Integrated soil fertility management operational definition and consequences for implementation and dissemination.OutlookAgriculture. 39: 17-24.

Vlaming, J., Bosch, H. van de, Wijk, M.S. van, Jager, A. de, Bannink, A. \&Keulen, H. 2001.Monitoring Nutrient Flows and Economic Performance in Tropical Farming Systems (NUTMON). NUTMON Tool Box, Wageningen.

Watson, C.A., Bengtsson, H., Ebbesvik, M., Loes, A-K., Myrbeck, Å., Salomon, E., Schroder, J. \& Stockdale, E.A. 2002. A review of farm-scale nutrient budgets for organic farms as a tool for management of soil fertility. Soil Use and Management 18, 264-273.

Wezel, A.; Casagrande, M.; Celette, F.; Vian, J.F.; Ferrer, A.; Peigné, J.2014.Agroecological practices for sustainable agriculture: A review. Agron. Sustain. Dev., 34, 1-20.

Whalen, J.K. and Chang, C. 2001. Phosphorus accumulation in cultivated soils from long-term annual applications of cattle feedlot manure.Journal of Environmental Quality30: 229-37.

Woodley, A., Audette, Y., Fraser, T., Arcand, M., Voroney, P., Knight, D., \& Lynch, D. H. 2014. Nitrogen and Phosphorus Fertility Management in Organic Field Crop Production.In R. C. Martin \& R. MacRae (Eds.), Managing Energy, Nutrients and Pests in Organic Field Crops (pp. 59-106) CRC Press.

Zingore S, Murwira HK, Delve RJ, 2007 Influence of nutrient management strategies on variability of soil fertility, crop yields and nutrient balances on smallholder farms in Zimbabwe AgricEcosyst Environ 119: 112-126. 